\title{
Designing E-Worksheet Based On Problem-Based Learning To Improve Critical Thinking
}

\author{
Sigit Sujatmika ${ }^{1}$, Muhammad Irfan $^{2}$, Tias Ernawati $^{3}$, Astuti Wijayanti ${ }^{4}$, Sri Adi Widodo ${ }^{5}$, \\ Ayu Fitri Amalia ${ }^{6}$, Heri Nurdiyanto ${ }^{7}$, Robbi Rahim ${ }^{8}$ \\ \{ sujatmika@ustjogja.ac.id ${ }^{1}$, muhammad.irfan@ustjogja.ac.id2, tias.ernawati@ustjogja.ac.id ${ }^{3}$, \\ astuti.wijayanti@ustjogja.ac.id4, sriadi@ustjogja.ac.id5, \\ ayufitriamalia@gmail.com ${ }^{6}$,herinurdiyanto@gmail.com ${ }^{7}$, robbirahim@ieee.org $^{8}$ \} \\ Universitas Sarjanawiyata Tamansiswa ${ }^{123456}$ Jl. Kusumanegara 157 Yogyakarta 55165 \\ STMIK Dharma Wacana ${ }^{7}$.Jl.kenanga No.03 Mulyojati 16C Metro Lampung, 34125 \\ STIM Sukma Medan ${ }^{8}$, Sumatra Utara, Indonesia
}

\begin{abstract}
Critical thinking is an important aspect of education. The ability to think critically is needed in achieving success for the future. Based on observations, it was found that students' critical thinking skills were still low. If a solution is not sought, this will affect the quality of graduates. The answer taken is to improve the quality of learning through the use of PBL-based E-Worksheet. The PBL model was chosen because it was able to develop critical thinking. The development of E-Worksheet needed because all this time the worksheet that used by lecturers in the form of paper printing so they only able to display images and writings. By developing an E-Worksheet capable of displaying writing, image, sound, video and interactive so that it is attractive to students. This development research procedure was adapted from Thiagarajan, Semmel, \& Semmel which involved 4 steps that is define, design, develop, and deseminate.
\end{abstract}

Keywords: Designing E-Worksheet, PBL, Critical Thinking

\section{Introduction}

Critical thinking is a popular topic among researchers [1]-[4], with critical thinking a person can improve his ability to solve problems[5]. Developing critical thinking skills is an important aspect of education [6], because it is needed to achieve success when students are outside of school [7]-[9], students are able to clarify, think deeply, and become problem solvers in social life [10].

Based on observations during learning, problems were still found related to students' critical thinking skills. During the lecture, there were still students who were not active in discussion activities, difficult to express opinions, reluctant to answer questions given by lecturers and the ability to answer low-level analysis questions. This shows that students' critical thinking skills need to be improved.

The ability to think critically can be improved through learning. In a learning, an appropriate learning model is needed to improve critical thinking skills. One learning model that can improve critical thinking skills is Problem-Based Learning (PBL). The definition of PBL is a learning model that is designed so that students can learn from the problems given, and are solved [11]. The functions possessed by PBL include questions or problems as a stimulus, interdisciplinary focus, authentic investigation, producing and presenting work, and 
collaboration [12]. The steps of learning activities with the PBL approach are as follows: reviewing and presenting problems; strategize; implement strategies; discuss and evaluate results [13].

PBL presents contextual problems, so it requires analytical skills for students to solve the problems presented [14]-[16]. PBL can be applied to courses in science, which includes many issues in life. One of the courses that represents Health Sciences. In this course, there are many issues about health issues related to the complex social conditions of the community. Therefore, it requires high-level analysis to solve it. For example is the material of respiratory system health which is affected by air pollution and cigarette smoke. To solve this problem requires complex and critical thinking.

In each learning including using PBL, teachers need to use learning tools [5], [17]-[19]. One of the learning devices used is worksheet. Worksheets used in learning are usually paper based, so that the costs incurred are large, students quickly feel bored, and less utilize technology development. There needs to be an interactive worksheet so students do not get bored quickly. In addition, it can save costs. Therefore, an electronic worksheet needs to be developed (EWorksheet). Later, E-Worksheet is designed to be accessible using laptops, PC's, smartphones and tablets. Students are also accustomed to using computer and gadget technology in lectures so E-Worksheet will be easily accepted. With this easy access, it is hoped that students will be more flexible in learning [20].

Based on this, it is necessary to develop PBL-based E-Worksheets so that students' critical thinking skills can improve. The hope is that when students' critical thinking skills increase, they are able to develop their knowledge and become a problem solver in community life. This study aims to prepare before the research and finalize the concept and design of the research to be carried out.

\section{Method}

This article is a form of pre-research study. The method used is qualitative descriptive analysis. From this step a development research design will be produced. The resulting design results will be used in subsequent research activities. Literacy studies are conducted to get theoretical support for learning plans and E-Worksheet designs. The literacy used is related to how to develop a product, how to design learning media, understand PBL principles, understand critical thinking and how to grow in students, and how to develop critical thinking through PBL methods that are packaged in E-Worksheet form.

\section{Discussion}

\section{A. Product Development Procedures}

The research method used here uses four steps or development procedures, that is define, design, develop, and disseminate [21]. In the first step, In the first step conducted with theoretical studies and empirical studies on courses. The courses taken are Health Sciences courses. The material in the Health Sciences lecture is related to human health and the environment. Some topics discussed include general health, principles of nutrition science, health of the digestive system, breathing, circulation, excretion, reproduction, coordination, exercise, and public health, infectious and non-infectious diseases. Of these topics, researchers 
took three topics, namely the health of the digestive system, the health of the respiratory system, and the health of the circulatory system. The selection of this material was taken by considering the level of difficulty of the material, the number of problems that can be conveyed for discussion, and various real-life problems related to topics that can train critical thinking. Researchers assume that the theme is suitable for learning with PBL. Empirical study by reviewing student characteristics, curriculum and learning process. In addition, researchers also took references from books to add insight into the preparation of E-Worksheet development and how to increase critical thinking through teaching materials.

Second step, developing the initial product in the form of a draft E-Worksheet that is adapted to the PBL syntax. The stages of preparing E-Worksheet are: developing concepts with problem identification, formulating goals, analyzing learning needs, analyzing the character of users, planning and following E-Worksheet software [22]. The Design Phase includes designing software that includes physical, function design, and logic design. Followed by developing a flow chart to visualize the product workflow from beginning to end. Collecting Stages materials: collection of lecture materials needed to make products. Assembly stage: compile text of the lecture material that is included in each frame or referred to as screen mapping.

The third step is done by an expert review, involving media experts and allied lecturers. This allied lecturer is from another university in Jogjakarta. The draft E-Worksheet is submitted to experts to be validated and given input to be more qualified. Consisting of design experts, media experts, and subject matter experts. This expert review is used as a reference in revising the draft E-Worksheet. Expert input relates to the correctness of the concept, the quality of design, packaging, and ease of operation and how the effort to make the draft E-Worksheet can increase the critical level of students. The results of this stage are in the form of a revised draft E-Worksheet.

The fourth step of the trial in small groups involves students through focus group discussion. At this stage the draft E-Worksheet was again tested by involving users on a small scale. Students try to use E-Worksheet and are asked to give input or suggestions. This input can be in terms of ease of language, design or appearance, ease of use, and impression after using. The researcher also observed as long as students used the draft E-Worksheet and collected data about the increase or change in critical thinking of students. The results of this stage are the draft E-Worksheet which has been revised based on input from users. Overall, there are two trials and a summary as in Table 1 . below.

Table 1. Trial For E-Worksheet

\begin{tabular}{|c|c|c|c|c|}
\hline $\begin{array}{c}\text { Trial } \\
\text { Stage }\end{array}$ & Sample & $\begin{array}{c}\text { Characteristic of } \\
\text { Sample }\end{array}$ & Sampling & Result Of Trial \\
\hline $\begin{array}{l}\text { Expert } \\
\text { judgment }\end{array}$ & 3 & $\begin{array}{l}\text { Experts in media } \\
\text { design, topic, languages }\end{array}$ & Purpose & $\begin{array}{l}\text { Qualitative } \\
\text { (Delphi } \\
\text { technique), draft } \\
\text { of product. }\end{array}$ \\
\hline $\begin{array}{l}\text { Small } \\
\text { group }\end{array}$ & $5-10$ & Product user & Random & $\begin{array}{l}\text { Product } \\
\text { compatibility } \\
\text { with users }\end{array}$ \\
\hline
\end{tabular}

Based on Table 1. the first trial phase involved several experts namely experts in media design or development, experts in topic of study, and experts in evaluation including language. Researchers plan to involve at least 3 experts in this study. For the small-scale trial phase 
involving students in small groups of 5 to 10 students. Those selected are students who have attended Health Sciences courses so that they already have experience. Through this experience students can provide input that supports product development.

In the curriculum of Indonesian university, it is stated that generic 6 levels description is capable of utilizing science and technology in its field of expertise and is able to adapt to the situation faced in solving problems. From this description, learning activities with problembased learning models strongly support curriculum achievement. The development of EWorksheet utilizes technology to support student learning more attractive, practical, and efficient. Through the development of E-Worksheet, it is also expected to support the achievement of learning with the PBL model.

\section{B. Problem Based Learning}

Educators should be mindful that learning process can enhance students' cognitive, affective, and psychomotor abilities [23]. Learning activities with PBL models involve students in groups and invite students to solve problems that have been designed by the teacher in groups. PBL plays a role in placing students at the center of the instructional paradigm. This section is able to direct students to control their learning process by identifying what they want to know, controlling existing problems, and finding the source of information needed. Furthermore, the main goal of student-centered learning is to be creative to find effective problem-solving strategies. Such a strategy will have an effect on students to be able to apply the patterns that have been acquired during learning, to be applied to similar problems. Then students will be able to apply various general approaches to the problem [24]-[26]

PBL has the character that learning activities start from giving problems that are in accordance with the real world, students work in groups and formulate problems and examine knowledge gaps between members, find their own literacy or theories related to the issues discussed, and report solutions that have been obtained to overcome the problem [26]. In this activity, educators act more as facilitators. In the learning process, educators are more important to design a form of problems that will be discussed by students, rather than giving material through lectures [27]. Educators can also provide assistance or instructions on reading sources that can be used. Through PBL learning, students will be more active and student-centered learning.

PBL is effective in providing the environment to learn a certain knowledge [26]. This PBL is able to develop skills in students related to problem solving skills in their lives, training to work together in teams and training students' skills to communicate. PBL will shape the skills of students to self directed, think metacognitive, smart in exploring knowledge or information, collaborative, and all of this is needed by them in the world of work [28]. From the two pendpat above can be concluded that PBL is able to optimize the many capabilities that exist in students which in turn will benefit students in their life success.

The things that are important attention to PBL are how the problem is given and the legitimacy. If too many problem frameworks are given, the problem space becomes less realistic [29]. Students face the risk of finding solutions directly rather than developing their own solutions. On the other hand, if it is too little it might just flood students with the complexity of the problem and prevent them from developing solutions to the problems that are given [30].

In formulating problems in learning a teacher needs to present it in a form of inappropriate performance, conditions that require attention or improvement, activities to find better ways or new things, phenomena that have not been explained or remain a mystery, various forms of inequality in information and knowledge, matters related to how to make decisions [28]. As an example for material related to respiratory system health can begin with problems like "Based 
on the results of the study showed that people who actively exercise regularly and smoke have a better level of health than people who do not smoke but rarely exercise. This fact can trigger the public's reluctance to stop smoking. What's the solution?

\section{Critical Thinking}

PBL is able to optimize students' ability to solve real-life problems [31], [32]. There is a part in PBL syntax able to train students to be critical thinking [3], [6], [8]. Researchers also assumed that through the implementation of sustainable PBL will improve critical thinking skills.

Critical thinking is a reasoned and reflective way of thinking by emphasizing decision making about what to believe or do [4], [6]. In the background of the problem, the author linked critical thinking patterns to the current rampant hoax news [33]. Critical thinking can be a solution. Critical thinking learning is not an easy job [1], [4], [8], [9]. Personality and cultural background can influence the effort to think critically about a life problem [33]. In addition, emotional conditions are influential in critical thinking [34].

According to the opinion of R. Ennis [35], it is better to understand a person's tendency and ability to be a critical thinker through 1) looking for clear statements based on each question, 2) trying to find reasons, 3) trying to dig up information properly, 4) using credible sources and mentioning it, 5) observing the situation and conditions thoroughly, 6) trying to stay relevant to the main idea, 7) reminding the original and fundamental interests, 8) looking for alternatives, 9) thinking and open-minded, 10) taking a position for compelling evidence to take action, 11) looking for explanations as much as possible, 12) be systematic with parts of the whole problem and 13) sensitive to the level of knowledge or expertise of others. From the explained trends, the authors assumed that there is a very dean relationship between PBL and efforts to think critically. Starting from the existence of a problem to be solved.

Beyer [35] summarizes critical thinking skills through the following actions 1) determine the credibility of a source, 2) distinguish between relevant and irrelevant matters, 3) distinguish facts from assessment 4) describe and evaluate unspoken opinions, 5) look for bias, 6) Identifying points of view a matter of and 7) evaluate evidence offered to support recognition. From the stated criteria, critical thinking skills can be grown through PBL. It is clear that critical thinking supported the success of PBL learning.

Efforts to improve critical thinking can be done in several ways (1) the reader must read critically as well due to critical thinking, (2) the ability for analysis improving done through group discussions, the best solution for a problem founding, the positive and negative impacts discussion, (3) observation ability improvement done by in-depth observation activities (4) increasing of curiosity, skill in asking, and reflection ability, (5) metacognition the ability to understand their own ways of thinking, (6) observing "models" in critical thinking has criteria including being able to give reasons for action clearly, responsibly, recognizing confusion or uncertainty, and not changing the response to unwarranted situations, (7) Maximum discussion between group members [35].

\section{Learning Activity in Class}

In the classroom implementation, PBL involves learning groups with small members. The main purpose of small group learning is to simulate a realistic team-based work environment. Another goal is to foster community practices that will provide group members with (1) opportunities for reciprocal involvement, (2) joint efforts, and (3) joint repertoires [36]. 
PBL implementation can be done through 7 steps. Step 1: Clarify concepts or terms that do not have clarity. Step 2: Stage formulating the problem. Step 3. Stages analyze a problem. Step 4: Formulate ideas and systematically analyze them in depth. Step 5: Formulate learning objectives (groups can formulate the objectives of learning based on the questions in step number 4. Step 6: look for various additional information from various sources. Step 7: Synthesize by combining and testing new information obtained [1], [26], [28]

The next analysis to integrate the process of increasing critical thinking in a PBL-based EWorksheet. The author chooses the E-Worksheet design that follows the PBL with 7 steps, after that at each step taken is given a stimulus to increase critical thinking. Because PBL is a learning that puts forward problem solving or finding various solutions to a problem, while critical thinking is related to analytical activities to determine actions, PBL must involve critical thinking. Therefore, the authors argue that PBL will increase students' critical thinking ability.

\section{Conclusion}

The development of E-Worksheet based on PBL applies four steps from Thiagarajan, Semmel, \& Semmel. That are define, design, develop, and deseminate. This E-Worksheet has the advantage of being multimedia and interactive, which cannot be done by paper-based worksheet. PBL is used using 7 steps and each step is given a stimulus or activity that aims to improve critical thinking.

\section{References}

[1] A. Martyanti and Suhartini, "Etnomatematika: Menumbuhkan Kemampuan Berpikir Kritis Melalui Budaya," Indomath Indones. Math. Edcuation, vol. 1, no. 1, pp. 35-41, 2018.

[2] N. M. Fuad, S. Zubaidah, S. Mahanal, and E. Suarsini, "Improving Junior High Schools' Critical Thinking Skills Based on Test Three Different Models of Learning," Int. J. Instr., vol. 10, no. 01, pp. 101-116, 2017.

[3] L. R. Novick and K. M. Catley, "Fostering 21st-century evolutionary reasoning: Teaching tree thinking to introductory biology students," CBE Life Sci. Educ., vol. 15, no. 4, pp. 1-12, 2016.

[4] H. Nold, "Using Critical Thinking Teaching Methods to Increase Student Success : An Action Research Project," Int. J. Teach. Learn. High. Educ., vol. 29, no. 1, pp. 17-32, 2017.

[5] S. A. Widodo, Turmudi, J. A. Dahlan, Istiqomah, and H. Saputro, "Mathematical Comic Media for Problem Solving Skills," in International Conference on Advance \& Scientific Innovation, 2018, pp. 101-108.

[6] A. Lubezky, Y. J. Dori, and U. Zoller, "Hocs-Promoting Assessment of Students' Performance on Environment-Related Undergraduate Chemistry," Chem. Educ. Res. Pract., vol. 5, no. 2, p. 175, 2004.

[7] A. Astin, What matters in college: Four critical years revisited. San Fransisco: 
Jossey-Bass, 1993.

[8] A. Gellin, "The Effect of Undergraduate Student Involvement on Critical Thinking: A Meta-Analysis of the Literature 1991-2000," J. Coll. Stud. Dev., vol. 44, no. 6, pp. 746-762, 2003.

[9] N. L. R. Stedman and B. L. Adams, "Identifying Faculty's Knowledge of Critical Thinking Concepts and Perceptions of Critical Thinking Instruction in Higher Educaiion," NACTA J., vol. 56, no. 2, pp. 9-14, 2012.

[10] P. Birjandi and M. Bagherkazemi, "The Relationship between Iranian EFL Teachers' Critical Thinking Ability and their Professional Success," English Lang. Teach., vol. 3, no. 2, pp. 135-145, 2010.

[11] R. Arends and A. Kilcher, Teaching for Student Learning: Becoming an Accomplished Teacher. New York: Taylor\&Francis Group, 2010.

[12] R. Arends and S. Castle, Learning to Teach. New York: McGraw-Hill, 2012.

[13] P. D. Eggen and D. P. Kauchak, Strategies for teacher teaching content and thinking skills. Boston: Allyn and Bacon. Boston: Allyn \& Bacon, 1996.

[14] Syahrir and Susilawati, "Pengembangan Modul Pembelajaran Matematika SMP," J. Ilm. Mandala Educ., vol. 1, no. 2, pp. 162-171, 2015.

[15] J. Good, K. Howland, and L. Thackray, "Problem-based learning spanning real and virtual words: a case study in Second Life," Alt-J, vol. 16, no. 3, pp. 163-172, 2008.

[16] D. Jonassen, "Interdisciplinary Journal of Problem-Based Learning Supporting Problem Solving in PBL Supporting Problem Solving in PBL," Interdiscip. J. Probl. Learn., vol. 5, no. 2, pp. 95-119, 2011.

[17] S. A. Widodo, R. C. I. Prahmana, A. S. Purnami, and Turmudi, "Teaching materials of algebraic equation," in Journal of Physics: Conference Series, 2018, vol. 943, no. 1.

[18] S. A. Widodo, "Selection of Learning Media Mathematics for Junior School Students," Turkish Online J. Educ. Technol., vol. 17, no. 1, pp. 154-160, 2018.

[19] S. A. Widodo, R. C. I. Prahmana, A. S. Purnami, and Turmudi, "Teaching materials of algebraic equation,” J. Phys. Conf. Ser., vol. 943, no. 01, 2017.

[20] M. Irfan, "Pemanfaatan Gadget Dalam Pembelajaran Matematika serta Pengaruhnya Pada Mahasiswa yang Mengalami Math-Anxiety Di Universitas Sarjanawiyata Tamansiswa pada Mata Kuliah Persamaan Differensial," Sci. TECH J. Ilm. Ilmu Pengetah. dan Teknol., vol. 1, no. 1, 2015.

[21] S. Thiagarajan, D. S. Semmel, and M. I. Semmel, Instructional Development for Training Teachers of Exceptional Children: A Sourcebook, no. Mc. Bloomington: Center for Innovation in Teaching the Handicappe, Indiana University, 1974.

[22] Soenarto, "Metodologi Penelitian Pengembangan Untuk Peningkatan Kualitas Pembelajaran," 2005.

[23] S. Sujatmika, D. Hasanah, and L. L. Hakim, "Effect of quantum learning model in improving creativity and memory," J. Phys. Conf. Ser., vol. 1006, no. 1, 2018. 
[24] J. P. Mestre, R. J. Dufresne, W. J. Gerace, and P. T. Hardninan, "Promoting Skilled Problem-Solving Behaviour Among Begning Physics Students," Journals Res. Sci. Teach., vol. 30, no. 3, pp. 303-317, 1993.

[25] W. J. Leonard, R. J. Dufresne, and J. P. Mestre, "Using Qualitative Problem-Solving Strategies to Highlight the Role of Conceptual Knowledge in Solving Problems," Am. J. Phys., vol. 64, no. 12, pp. 1495-1503, 1996.

[26] E. F. W. Puadi and Muhammad Irfan Habibie, "Implementasi PBL Berbantuan GSP Software Terhadap Peningkatan Kemampuan Pemecahan Masalah Matematik Siswa," Indomath Indones. Math. Edcuation, vol. 1, no. 1, pp. 19-26, 2018.

[27] M. Irfan, T. Nusantara, S. Subanji, and Sisworo, "Why Did the Students Make Mistakes in Solving Direct and Inverse Proportion Problem ?," Int. J. Insights Math. Teach., vol. 01, no. 1, pp. 25-34, 2018.

[28] M. T. Amir, Inovasi Pendidikan Melalui Problem Based Learning (Bagaimana Pendidik Memberdayakan Pemelajar di Era Pengetahuan). Jakarta: Kencana Prenada Media Group, 2009.

[29] M. Irfan, S. Sudirman, and R. Rahardi, "Characteristics of students in comparative problem solving,” J. Phys. Conf. Ser., vol. 948, pp. 1-11, 2018.

[30] D. O. Neville and D. W. Britt, "A Problem-Based Learning Approach to Integrating Foreign Language Into Engineering,” Foreign Lang. Ann., vol. 40, no. 2001, pp. 226246, 2007.

[31] N. B. Zeliha, "The problem-based learning process: Reflections of pre-service elementary school teachers," Educ. Res. Rev., vol. 12, no. 4, pp. 177-188, 2017.

[32] S. Winarno, K. S. Muthu, and L. S. Ling, "Direct Problem-Based Learning (DPBL): A Framework for Integrating Direct Instruction and Problem-Based Learning Approach,” Int. Educ. Stud., vol. 11, no. 1, p. 119, 2017.

[33] M. Irfan, "Role of Learning Mathematics in the Character Building," pp. 599-604, 2016.

[34] M. Irfan, “Analisis Kesalahan Siswa dalam Pemecahan Masalah Berdasarkan Kecemasan Belajar Matematika,” Kreano, J. Mat. Kreat., vol. 8, no. 2, pp. 143-149, 2017.

[35] Z. I. Hassoubah, Developing Creative \& Critical Thinking Skills. Bandung: Yayasan Nuansa Cendekia, 2004.

[36] M. Graven and S. Lerman, "BOOK REVIEW Wenger, E. (1998).," J. Math. Teach. Educ., no. 1998, pp. 185-194, 2003. 